\title{
Massive compensatory hyperinflation
}

\author{
Karan Madan, Navneet Singh
}

Department of Pulmonary Medicine, PGIMER,

Chandigarh, India

\section{Correspondence to}

Dr Navneet Singh,

navneetchd@hotmail.com
To cite: Madan K, Singh $\mathrm{N}$. BMJ Case Rep Published

online: [please include Day

Month Year] doi:10.1136/

bcr-2013-008668

\section{DESCRIPTION}

A 14-year-old girl presented with a 1-year history of insidious onset dyspnoea. Three years previously, she had been treated for 6 months with directly observed antituberculous treatment for sputum smear positive pulmonary tuberculosis (TB) and the treatment was successful.

Chest radiograph demonstrated gross mediastinal shift to the right side with hyperinflated left hemithorax (figure 1). A CT scan demonstrated massive hyperinflation and anterior herniation of left lung across the midline to the right side with complete right lung collapse (figure 2). Flexible bronchoscopy demonstrated tight cicatricial stenosis of the right main bronchus. A diagnosis was made of massive compensatory hyperinflation of the left lung secondary to post-tubercular right main bronchus stenosis and destroyed right lung. Flexible bronchoscopic balloon dilation of right main bronchus was unsuccessful owing to the extremely tight nature of the stenosis. As the patient had symptoms only on more than usual levels of exertion, she was reassured and advised for periodic follow-up.

Massive compensatory unilateral pulmonary hyperinflation (also described as pseudohorseshoe lung) is a consequence to a number of conditions leading to contralateral lung volume loss. ${ }^{1}$ In our patient, tuberculous lung parenchymal and endo-

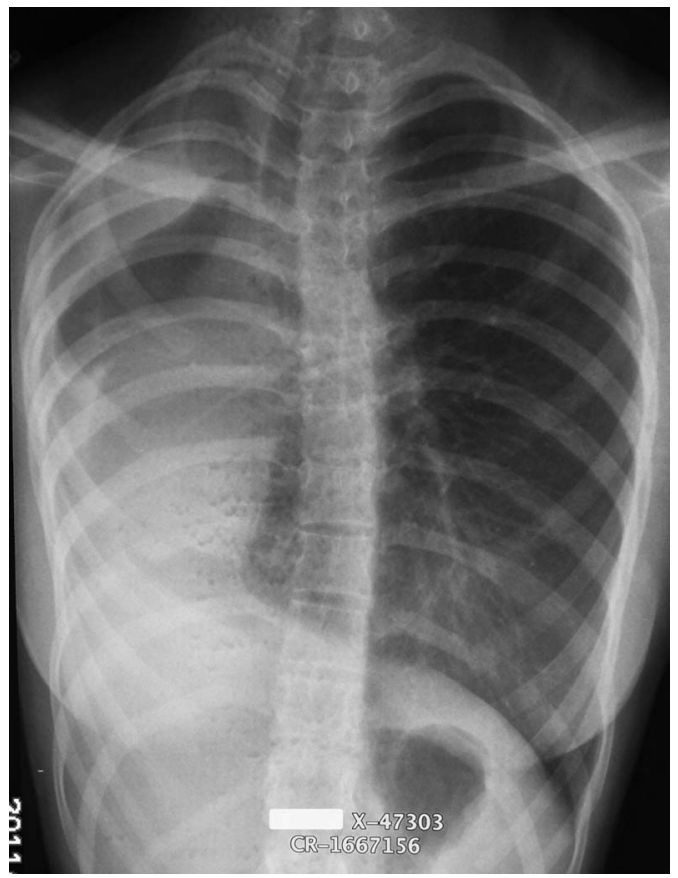

Figure 1 Posteroanterior chest radiograph demonstrating mediastinal shift to the right side with grossly hyperinflated left lung.

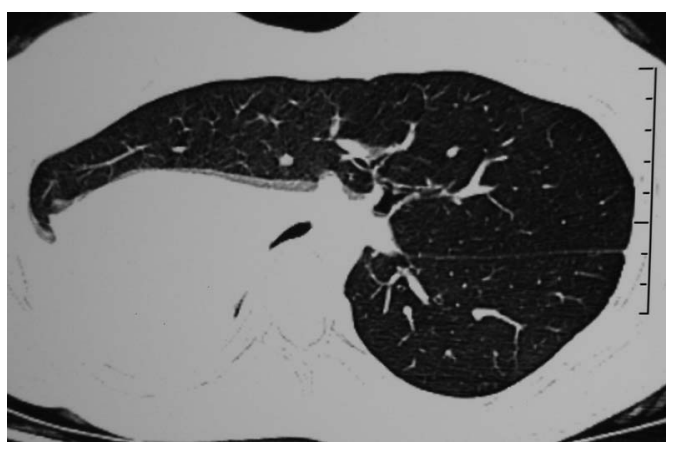

Figure 2 High-resolution CT of the thorax demonstrating hyperinflation and anterior herniation of left lung to the right side along with complete collapse and volume loss of the right lung. The right main bronchus appears narrowed.

bronchial involvement led to slowly progressive bronchostenosis and extensive right lung volume loss accompanied by simultaneous progressive hyperinflation of left lung. Such degrees of extensive unilateral lung destruction are often seen with TB. On the other hand, true horseshoe lung is a rare congenital anomaly in which the bases of the right and the left lungs are fused together by a narrow isthmus posterior to the cardiac apex. ${ }^{2}$

\section{Learning points}

- Massive compensatory hyperinflation can occur as a consequence to a number of conditions leading to extensive unilateral pulmonary destruction/volume loss.

- The degree of hyperinflation can often be tremendous in which the hyperinflated lung herniates anteriorly across the midline and may nearly totally occupy the contralateral hemithorax.

- Management of compensatory pulmonary hyperinflation is conservative.

Competing interests None.

Patient consent Obtained.

Provenance and peer review Not commissioned; externally peer reviewed.

\section{REFERENCES}

1 Singh N, Agarwal R, Gupta D. Pseudohorseshoe lung. CMAJ 2008; $178: 394$

2 Ersoz A, Soncul H, Gokgoz L, et al. Horseshoe lung with left lung hypoplasia. Thorax 1992;47:205-6. 
Copyright 2013 BMJ Publishing Group. All rights reserved. For permission to reuse any of this content visit http://group.bmj.com/group/rights-licensing/permissions.

BMJ Case Report Fellows may re-use this article for personal use and teaching without any further permission.

Become a Fellow of BMJ Case Reports today and you can:

- Submit as many cases as you like

- Enjoy fast sympathetic peer review and rapid publication of accepted articles

- Access all the published articles

- Re-use any of the published material for personal use and teaching without further permission

For information on Institutional Fellowships contact consortiasales@bmjgroup.com

Visit casereports.bmj.com for more articles like this and to become a Fellow 